\title{
Implementasi Keselamatan dan Kesehatan Kerja di Puskesmas: Studi Kasus di Kabupaten Pekalongan
}

\author{
Fitria Qotrotun Nada*, Hanifa Maher Denny ${ }^{* *}$, Yuliani Setyaningsih ${ }^{* *}$ \\ ${ }^{* * * *)}$ Fakultas Kesehatan Masyarakat, Universitas Diponegoro \\ Email: fitriaqnada@gmail.com, hanifadenny@live.undip.ac.id, yulianifkm@live.undip.ac.id
}

\begin{abstract}
The regulation of "PERMENKES NO. 52/2018" stipulates that a health care service institution is requied to implement the occupational health program for its employees This study utilized qualitative methods to explain the implementation of occupational safety and health in a health care setting. The main informants were 5 people and triangulations were 2 people. The instruments in this study used indepth interview guidelines and observation sheets. The study site was conducted in pekalongan district. The result indicated that Delegation or SK, Resources, Waste Treatment, Incident Reporting, Occupational Disease Reporting, Health care and Emergency Response accordance with the regulation. However, OSH Policy, Annual Work Plan, The level of compliance with $\mathrm{OSH}$ implementation and The Socialization of SOP didn't accordance with the regulation. Based on the results of research on the implementation of 10 indicators of success OSH Primary Health Care, there are 4 variables (OSH Policy, Annual Work Plan, The level of compliance with $\mathrm{OSH}$ implementation and The Socialization of SOP) must be improved.
\end{abstract}

Keywords: Implementation of $\mathrm{OSH}, \mathrm{OSH}$ Success Indicators, Health Center

\section{PENDAHULUAN}

Kesehatan merupakan salah satu hak dasar manusia. Didalam amanat Pasal $28 \mathrm{H}$ ayat (1) UUD 19451945 tentang penyediaan fasilitas pelayanan kesehatan dan fasilitas pelayanan umum yang layak yang merupakan bagian dari sumber daya kesehatan yang sangat diperlukan dalam mendukung penyelenggaraan upaya kesehatan adalah Puskesmas. ${ }^{1}$

Kesehatan Kerja ditujukan untuk melindungi pekerja agar hidup sehat dan terbebas dari gangguan kesehatan serta pengaruh buruk yang diakibatkan oleh pekerjaan. Upaya kesehatan kerja yang dimaksud meliputi pekerja disektor formal dan informal dan berlaku bagi setiap orang selain pekerja yang berada di lingkungan tempat kerja. ${ }^{2}$

Puskesmas memiliki potensi bahaya yang berpengaruh kepada petugas, pasien, pengunjung dan masyarakat sekitar. Potensi bahaya meliputi fisik, kimia, biologi, ergonomik dan psikososial. Potensi bahaya biologis merupakan bahaya paling sering yang menyebabkan gangguan kesehatan di puskesmas. ${ }^{2}$

Pada tahun 2010, WHO kasus infeksi akibat tusukan jarum (NSI) yang terkontaminasi virus. Akibat dari Tusukan Jarum (NSI) tersebut mengakibatkan sebanyak $32 \%$ petugas kesehatan terinfeksi virus hepaitis B, $40 \%$ petugas 
kesehatan terinfeksi virus hepaitis $\mathrm{C}$ dan $5 \%$ petugas kesehatan terinfeksi HIV. ${ }^{1}$

Puskesmas X merupakan Puskesmas yang berada di bawah naungan Dinas Kesehatan Kabupaten Pekalongan dengan tipe non rawat inap. Wilayah kerja Puskesmas X berjumlah 16 Desa dengan jumlah penduduk 54.106 Jiwa. Jumlah Sumber Daya Manusia (SDM) di Puskesmas X berjumlah 64. Dari hasil observasi awal diketahui bahwa di Puskesmas $\mathrm{X}$ terdapat belum adanya poster untuk menggunakan APD sesuai bahaya ditempat kerja terutama menggunakan sarung tangan sebelum melakukan tindakan invansive. Dari hasil wawancara singkat kepada Penanggung Jawab K3 pada tahun 2018 dari 50 tenaga kesehatan diketahui $50 \%$ pernah mengalami tertusuk jarum suntik pada saat bekerja dan sebanyak $8 \%$ petugas kesehatan diperkirakan sakit akibat kerja. Puskesmas $\mathrm{X}$ telah terakreditasi madya dengan sudah memenuhi kriteria indikator akreditasi puskesmas tingkat madya pada tahun 2017 dan sedang mempersiapkan untuk akreditasi paripurna pada November 2019.

Indikator Keberhasilan K3 yang diatur didalam Pedoman K3 Puskesmas Kementerian Keseshatan RI tahun 2011 merupakan pedoman dalam melaksanakan K3 di Puskesmas. Didalamnya terdapat 10 Indikator dalam melaksanakan K3 di Puskesmas. 10 indikator tersebut meliputi Komitmen dan Kebijakan Kepala Puskesmas, Adanya SK Kepala Puskesmas Pelaksanaan K3 Puskesmas, Dokumen Tertulis Rencana K3 Dalam Bentuk Rencana Kerja Tahunan, Adanya Dukungan Sumber Daya, Tingkat Kepatuhan Pelaksanaan K3, Pembudayaan K3 melalui pemanfaatan SOP, Pengelolaan Limbah Angka Kecelakaan Kerja, Angka Penyakit Akibat Kerja (PAK), Pelayanan Kesehatan Kerja dan Tanggap Darurat. ${ }^{3}$ Dalam pelaksanaannya di Puskemas Wiradesa telah menerapkan Indikator tersebut akan tetapi terdapat beberapa indikator yang belum diterapkan.

\section{METODE PENELITIAN}

Penelitian ini menggunakan metode penelitian kualitatif. Metode penelitian yang digunakan adalah wawancara mendalam (indepth interview) pada subyek penelitian, observasi dan dokumentasi. Adapuntujuanpenelitianini untuk menggambarkan bagaimana implementasi Kesehatan dan Keselamatan Kerja (K3) pada Puskesmas X Kabupaten Pekalongan berdasarkan Indikator Keberhasilan K3.

Subyek penelitian yang digunakan dalam penelitian ini dipilih dengan menggunakan metode purposive sampling dengan validitas data menggunakantekniktriangulasi. Informan utama dalam penelitian ini terdiri dariPenanggung jawab Tim Tanggap Darurat, Penanggung jawab Pelayanan Kesehatan Kerja, Penanggung jawab Pengelolaan Limbah B3, Penanggung jawab Promosi Kesehatan, Ketua Tim PMKP.

Informan triangulasi terdiri dari Kepala Puskemas yang berperan dalam pembuatan kebijakan dan keputusan di Puskesmas serta Penanggung Jawab Pelaksanaan K3 di Puskesmas X. Metode pengolahan data dilakukan dengan teknik transkripping, koding, reduksi, penyajian data dan penarikan kesimpulan.

\section{HASIL DAN PEMBAHASAN Komitmen dan Kebijakan Puskesmas}

Komitmen pelaksanaan K3 di Puskesmas diwujudkan dalam bentuk penanadatanganan kesepakatan oleh seluruh pegawai Puskesmas setelah dilakukannya sosialisasi oleh Kepala Puskesmas. Dalam pelaksanaan K3 di Fasyankes harus ada komitmen dari pimpinan tertinggi Fasyankes yang dituangkan dalam kebijakan tertulis dan ditandatangani oleh pimpinan tersebut. $3,4,5,20,21$

Berdasarkan hasil wawancara mendalam menyatakan bahwa komitmen sudah dibuktikan dengan adanya SK Tim Pelaksanaan K3 meskipun belum adanya 
penandatangan bahwa Puskesmas telah berkomitem K3 dan tidak adanya kebijakan tertulis K3 di Puskesmas X. Pernyataan informan utama tersebut sesuai dengan pernyataan yang disampaikan oleh informan triangulas. Hal tersebut juga sesuai dengan hasil observasi yang telah dilakukan, yaitu tidak adanya tanda tangan komitmen terhadap K3 melainkan komitmen terhadap keselamatan pasien, mutu dan kinerja dan tidak ditemukan adanya kebijakan K3. Belum sesuainya komitmen dan kebijakan K3 dengan peraturan Peraturan Menteri Kesehatan No 52 Tahun 2018 Tentang K3 di Fasilitas Kesehatan. ${ }^{4}$

\section{SK Kepala Puskesmas tentang Pelaksanaan K3 Puskesmas}

Surat Keputusan Kepala Puskesmas yang dibuat tentang Pelaksanaan K3 Puskesmas, Tim Pelaksana K3 dan Tugas dan Fungsi Tim. Tim K3 di Fasyankes ditetapkan dengan Surat Keputusan Pimpinan Fasyankes yang memuat susunan organisasi, uraian tugas, dan tanggung jawab. ${ }^{4,7}$

Berdasarkan hasil wawancara mendalam menyatakan bahwa SK Tim Pelaksanaan K3 Puskesmas sudah ada dan sudah disahkan sejak awal tahun 2019. Didalam SK sudah tercantum nama anggota yang menjadi Tim K3 beserta tupoksinya Pernyataan informan utama tersebut sesuai dengan pernyataan informan triangulasi. Berdasarkan hasil observasi terdapat adanya SK Kepala Puskesmas tentang Kelompok Kerja Kesehatan dan Keselamatan Kerja yang telah disahkan pada awal tahun 2019 oleh Kepala Puskesmas. Hal tersebut sudah sesuai dengan peraturan Peraturan Menteri Kesehatan No 52 Tahun 2018 Tentang K3 di Fasilitas Kesehatan. ${ }^{4}$

\section{Dokumen Tertulis Rencana K3 Dalam Bentuk Rencana Kerja Tahunan}

Fasyankes harus membuat perencanaan K3 di Fasyankes yang efektif agar tercapai keberhasilan penyelenggaraan K3 di Fasyankes dengan sasaran yang jelas dan terukur. Penyusunan perencanaan harus memperhatikan peraturan perundangundangan, kondisi yang ada, dan berdasarkan hasil identifikasi risiko. ${ }^{4,7,22,23}$

Berdasarkan hasil wawancara mendalam menyatakan bahwa sudah adanya rencana kerja Tim K3 yang disusun berdasarkan kebutuhan dan rencana kerja wajib. Pernyataan seluruh informan utama tersebut sesuai dengan pernyataan yang disampaikan oleh informan triangulasi. Berdasarkan hasil observasi terdapat adanya rencana kerja K3 yang telah disetujui oleh Kepala Puskesmas terdapat beberapa hal yang belum sesuai dengan Peraturan Menteri Kesehatan No 52 Tahun 2018 Tentang K3 di Fasilitas Kesehatan, yaitu rencana kerja $\mathrm{K} 3$ yang disusun tidak berdasarkan resiko yang ada atau hasil dari identifikasi resiko melainkan berdasar kegiatan wajib dan hanya rencana kerja tambahan apabila dibutuhkan. $^{4}$

\section{Dukungan Sumber Daya}

Sumber daya menunjang atas keberhasilan implementasi K3 yang dibutuhkan dalam pelaksanaan kegiatan yaitu suatu keterampilan dan keahlian khusus yang harus dimiliki oleh tenaga kerja guna bisa melaksanakan pekerjaannya dengan baik. Sumber daya manusia harus memiliki keterampilan dan keahlian khusus perlu dilakukannya pelatihan atau peningkatan kompetensi di bidang K3 agar mampu meningkatkan keterampilan tentang pelaksanaan $\mathrm{K} 3$ di Puskesmas. Terdapat hal terpenting lainnya adalah sumber dana yang tersedia dalam menjalankan program K3., $, 8,9$

Berdasarkan hasil wawancara mendalam menyataka bahwa sudah adanya SDM yang berkompeten dibidang K3 dan hanya terdapat satu orang. Sudah dilaksanakannya pelatihan terkait K3 seperti pelatihan pelatihan workshop manajemen resiko, insiden keselamatan pasien, pencegahan infeksi, pelatihan 
APAR, pelatihan triage dan pelatihan simulasi keadaan darurat. Sudah adanya anggaran dana untuk program K3 dengan anggaran dana yang diberikan hanya berdasar kebutuhan program K3. Pernyataan seluruh informan utama tersebut sesuai dengan pernyataan yang disampaikan oleh informan triangulasi. Hal tersebut sudah sesuai dengan peraturan Peraturan Menteri Kesehatan No 52 Tahun 2018 Tentang K3 di Fasilitas Kesehatan. ${ }^{4}$

\section{Tingkat Kepatuhan Pelaksanaan K3}

Setiap Fasilitas Pelayanan Kesehatan harus melaksanakan PPI di Fasilitas Pelayanan melalui pembentukan Komite atau Tim PPI. PPI dilaksanakan melalui penerapan prinsip kewaspadaan standar. Prinsip utama standard precaution/kewaspadaan antara lain yaitu cuci tangan, pemakaian apd, pengelolaan jarum dan benda tajam, pengelolaan limbah medis dan non medis. ${ }^{4,10}$

Berdasarkan hasil wawancara mendalam menyatakan bahwa sudah terbentuknya Tim PPI. Terkait SOP standard precaution belum adanya SOP mencuci tangan. Terkait rewardandpunishment belum adanya pemberian penghargaan (reward) dan sudah adanya punishmet. Pernyataan seluruh informan utama tersebut sesuai dengan pernyataan yang disampaikan oleh informan triangulasi. Berdasarkan hasil observasi sudah adanya susunan organisai dan SK penunjukan Tim PPI. Adanya Tim PPI sudah sesuai dengan peraturan. ${ }^{32}$ Belum adanya SOP mencuci tangan dan pemberian reward belum sepenuhnya sesuai dengan Peraturan Menteri Kesehatan No 52 Tahun 2018 Tentang K3 di Fasilitas Kesehatan. ${ }^{4}$

\section{Pembudayaan K3 melalui pemanfaatan SOP}

Sosialisasi penting untuk dilakukan secara berkala agar pemahaman petugsas kesehatan meningkat sehingga penerapan SOP dapat berjalan. Beberapa program untuk mengkomunikasikan K3 yang telah dilakukan diantaranya adalah dengan adanya safety talk pada saat akan bekerja dan pergantian shift, adanya poster-poster $\mathrm{K} 3$, pertemuan bulanan $\mathrm{P} 2 \mathrm{~K} 3$, sosialisasi SOP K3, banner K3, buku saku patient safety. ${ }^{4,11,12,13}$

Berdasarkan hasil wawancara mendalam menyatakan bahwa sosialisasi SOP dilakukan pada saat rapat dan belum adanya jadwal yang terstruktur terkait sosialisasi. Pernyataan seluruh informan utama tersebut sesuai dengan pernyataan yang disampaikan oleh informan triangulasi. Berdasarkan hasil observasi belum adanya bentuk sosialisasi berupa poster promosi $\mathrm{K} 3$ dan poster penggunaan APD, hanya terdapat beberapa poster promosi kesehatan. Berdasar hal tersebut menurut Peraturan Menteri Kesehatan No 52 Tahun 2018 Tentang K3 di Fasilitas Kesehatan belum sesuai karena pada poin tugas dari tim K3 menyebutkan bahwa tugas dari Tim K3 adalah membantu pimpinan Fasyankes menyelenggarakan promosi. ${ }^{4}$

\section{Pengelolaan Limbah}

Pengelolaan limbah B3 secara aman dan sehat wajib dilakukan oleh Fasyankes sesuai standar dan peraturan yang ada. Pengelolaan limbah B3 dalam aspek K3 Fasyankes harus memastikan pelaksaan pengelolaan menjamin keselamatan dan kesehatan kerja SDM. ${ }^{4,14}$

Berdasarkan hasil wawancara mendalam menyatakan bahwa pengelolaan limbah B3 khususnya limbah medis padat menggunakan Pihak ke-3 sedangkan limbah medis cair dan domestik mampu di kelola sendiri. Sudah adanya SOP penyimpanan limbah B3, lembar data keselamatan, sarana keselamatan dan APD. Berdasarkan hasil observasi sudah adanya lembar perjanjian dengan pihak ketiga, SOP limbah B3, sarana keselamatan dan APD. Hal tersebut sudah sesuai dengan peraturan Peraturan Menteri 
Kesehatan No 52 Tahun 2018 Tentang K3 di Fasilitas Kesehatan. ${ }^{4}$

\section{Pelaporan Kecelakaan Kerja}

Fasyankes wajib melakukan pencatatan dan pelaporan penyelenggaraan K3 Fasyankes secara secara periodik. Pencatatan dan pelaporan secara semester meliputi kasus yang berhubungan dengan kejadian keselamatan dan kesehatan kerja. ${ }^{4,15,16}$

Berdasarkan hasil wawancara mendalam menyatakan bahwa sudah adanya SOP apabila terjadi kecelakaan kerja didalamnya memuat alur pelaporan dan tindak lanjut pelaporan. Berdasarkan hasil observasi tedapat SOP pelaporan kecelakaan kerja dan dokumen analisa dan tindak lanjut monitoring kecelakaan kerja. Hal tersebut sudah sesuai dengan peraturan Peraturan Menteri Kesehatan No 52 Tahun 2018 Tentang K3 di Fasilitas Kesehatan. ${ }^{4}$

\section{Pelaporan Penyakit Akibat Kerja (PAK)}

Penyakit Akibat Kerja adalah penyakit yang disebabkan oleh pekerjaan dan lingkungan kerja. Diagnosis menderita Penyakit Akibat Kerja berdasarkan surat keterangan dokter merupakan diagnosis jenis Penyakit Akibat Kerja yang dilakukan oleh dokter atau dokter spesialis yang berkompeten di bidang kesehatan kerja. Penyakit yang telah didiagnosis sebagai Penyakit Akibat Kerja dilakukan pencatatan dan pelaporan. ${ }^{17}$

Berdasarkan hasil wawancara mendalam menyatakan bahwa belum adanya pelaporan PAK karena penjelasan mengenai alur pelaporan dan tindak lanjut pelaporan ada didalam SOP Pelayanan Kesehatan. Berdasarkan hasil observasi tedapat SOP Pelayanan Kesehatan yang di dalamnya terdapat alur pelaporan apabila terindikasi dakit akibat kerja Hal tersebut sudah sesuai dengan peraturan Peraturan Menteri Kesehatan No 52 Tahun 2018 Tentang K3 di Fasilitas Kesehatan. ${ }^{4}$

\section{Pelayanan Kesehatan Kerja dan Tanggap Darurat}

Pelayanan kesehatan kerja terdiri atas pemeriksaan kesehatan sebelum bekerja, berkala dan khusus untuk petugas kesehatan yang paling berisiko di Puskesmas. Selain pelayanan kesehatan kerja terdapat hal terpenting juga yaitu terkait tanggap darurat bencana antaranya pembentukan panitia, pembuatan standar operasional prosedur (SOP) tanggap darurat, pemenuhan fasilitas dan pelatihan mengenai kebakaran. ${ }^{14,18,19,24-26}$

Berdasarkan hasil wawancara mendalam menyatakan bahwa sudah adanya pemeriksaan kesehatan awal bagi petugas baru bekerja, pemeriksaan kesehatan berkala dan pemeriksaan kesehatan khusus. sudah adanya Tim Tanggap Darurat atau Tim Red Code dengan petugas yang sudah terlatih. Hanya terdapat prosedur evakuasi yang telah dipasang berdampingan dengan jadwal petugas red code. sudah pernah dilakukannya simulasi keadaan darurat yang dilakukan bersama dengan Badan Penanggulangan Bencana Daerah (BPBD). Sudah dilakukannya mapping bahaya lingkungan kerja dengan cara melakukan pengukuran lingkungan kerja di setiap ruangan. Berdasarkan hasil observasi sudah sesuai dengan pernyataan seluruh informan. Hal tersebut sudah sesuai dengan peraturan Peraturan Menteri Kesehatan No 52 Tahun 2018 Tentang K3 di Fasilitas Kesehatan. ${ }^{4}$

\section{KESIMPULAN}

Puskesmas $\mathrm{X}$ merupakan tempat pelayanan kesehatan yang sudah memiliki komitmen K3 yang dibuktikan dengan ketersediaan SK Kepala Puskesmas tentang pelaksanaan $\mathrm{K} 3$ puskesmas serta SK Tim Pelaksanaan K3, tersedia sumber daya manusia yang kompeten dan didukungn dengan adanya pelatihan dan alokasi dana, tersedia Tim PPI dan SOP Tingkat Kepatuhan Kewaspadaan Standar, tersedia pengelolaan limbah B3 yang dilakukan oleh pihak ketiga, tersedia SOP 
dan APD terkait pengelolaan limbah, tersedia SOP pelaporan kecelakaan kerja, pelaporan penyakit akibat kerja serta tersedia Tim Tanggap Darurat atau Tim Red Code. Namun masih terdapat beberapa kendala terkait pelaksanaan K3 di Puskesmas X antara lain rencana kerja tahunan belum disusun berdasarkan hasil identifikasi risiko dan belum dilakukan sosialisasi SOP dalam membudayakan K3.

\section{UCAPAN TERIMA KASIH}

Penulis mengucapkan terima kasih kepada Puskesmas lokasi penelitian serta Dinas Kesehatan Kabupaten Pekalongan atas ijin yang diberikan untuk melaksanakan penelitian. Penulis juga mengucapkan terima kasih kepada seluruh responden yang bersedia berpartisipasi pada penelitian.

\section{DAFTAR PUSTAKA}

1. Wijayanti $\mathrm{R}$, et al. Identification, risk assesment and determining control in Gambirsari public health center Surakarta. Indones J Med Sci. 2017;4(2):150-6.

2. Saputra N, Saputri WC. Analysis Of Management Prevention And Fight Fire At The Health Center Of Cipayung East Jakarta. J Kesehat Masy. 2018;8(1):18-26.

3. Kementerian Kesehatan RI. Direktorat Jendral Bina Gizi dan KIA. Pedoman Keselamatan dan Kesehatan Kerja Puskesmas. Jakarta:Kementerian Kesehatan RI;2011.

4. Peraturan Menteri Kesehatan RI No 52 Tahun 2018 tentang Keselamatan dan Kesehatan Kerja di Fasilitas Kesehatan.

5. Ivana, Azza, Baju W dan Siswi J. Analisa Komitmen Manajemen Rumah Sakit (RS) Terhadap Keselamatan Dan Kesehatan Kerja (K3) Pada RS Prima Medika
Pemalang. JKM (e-Journal). 2014;2(1):35-41.

6. Suhadi, Rais MK. Perencanaan Puskesmas. Jakarta Timur: Buku Kesehatan; 2015.

7. Husein Umar. 2009. Rencana Kerja Perusahaan Yang Baik. Jakarta: Rajawali

8. L M, Kurniawidjaja. Teori dan Aplikasi Kesehatan Kerja. Jakarta: UI Press; 2012.

9. Bangun, Wilson. 2013. "Manajemen Sumber Daya Manusia". Jakarta : Erlangga.

10. Peraturan Menteri Kesehatan Nomor 27 Tahun 2017 tentang Pedoman Pencegahan dan Pengendalian Infeksi di Fasilitas Pelayanan Kesahatan.

11. Destari, Nurhuda, Baju W dan Ida W. Analisis Implementasi Promosi K3 Dalam Upaya Pencegahan Kecelakaan Kerja Di PT $\mathrm{X}$ (Proyek Pembangunan Gedung Y Semarang). JKM(e-Journal). 2017;5(1):397-404

12. Sari, Reny Yulita, dkk. Pengaruh Sosialisasi Sop Apd Dengan Perilaku Perawat Dalam Penggunaan Apd (Handscoon, Masker, Gown) Di Rsud Dr. H. Soewondo. Jurnal Keperawatan dan Kebidanan (JIKK). 2014.

13. Gibson JL, Ivancevich JM, Konopaske R. Organizations: Behavior, Structure, Processes. 14 edition. Dubuque, IA: McGraw-Hill Education; 2011. 640 p.

14. Triwibowo C, Erlisya M. Kesehatan Lingkungan dan K3. Yogyakarta: Nuha Medika; 2013.

15. Peraturan Menteri Tenaga Kerja No 1998 Tata Cara Pelaporan dan Pemeriksaan Kecelakaan.

16. Mentang, Marisca Imaculata Firani. Evaluasi Penerapan Sistem Manajemen K3 Pada Peningkatan Fasilitas PT. Trakindo Utama Balikpapan. Jurnal Sipil Statik. 2013;1(5):318-327. 
17. Peraturan Presiden RI Nomor 7 Tahun 2019 Tentang Penyakit Akibat Kerja.

18. Maharja, Rizky. Analisis Tingkat Kelelahan Kerja Berdasarkan Beban Kerja Fisik Perawat Di Instalasi Rawat Inap Rsu Haji Surabaya. The Indonesian Journal Of Occupational Safety And Health. 2015;4(1):93-102.

19. Arrazy, Sy afran, dkk. Penerapan Sistem Manajemen Keselamatan Kebakaran Di Rumah Sakit Dr. Sobirin Kabupaten Musi Rawas JIKM. 2014;5(2):105-111.

20. Undang-Undang Republik Indonesia Nomor 13 Tahun 2003 Tentang Ketenagakerjaan.

21. Efendi S. Organisasi dan Manajemen Pelayanan Kesehatan. Jakarta: Buku Kedokteran EGC; 2015

22. Adisasmito W. Sistem Kesehatan. Jakarta: Raja Grafindo Persada; 2014

23. Adisaputro, Gunawan, 2010, Manajemen Pemasaran (Analisis Untuk Perancangan Strategi Pemasaran), Sekolah Tinggi Ilmu Manajemen YKPN, Yogyakarta

24. Efendi, F. dan Makhfudli. Keperawatan Kesehatan Komunitas Teori dan Praktik dalam Keperawatan. Jakarta: Penerbit Salemba Medika; 2009.

25. Jeyaratnam J. Buku Ajar Praktik Kedokteran Kerja. Jakarta: Penerbit Buku Kedokteran EGC; 2009.

26. Hepiman, Fison. Rancangan dan Tanggap Darurat Terhadap Bahaya Kebakaran di Rumah Sakit dr. Ernaldi Bahar Palembang, Fakultas Kesehatan Masyarakat Universitas Sriwijaya, Inderalaya.2009. 